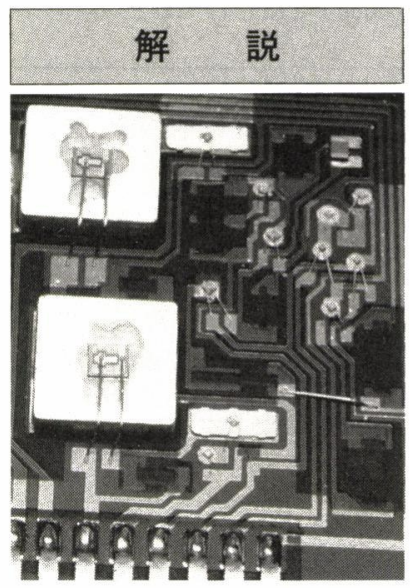

\title{
導電性ゴムの接続技術
}

Connection Technique of Conductive Rubber

\section{氷田 正樹*}

\section{1.はじめに}

導電性ゴムは, カーボンブラックや金属などの導電性 材料にゴムをマトリックスとして使用した複合導電材料 である。

ゴムは高弾性を有することから,一般の高分子材料の 特長である軽量, 易加工性に加之, 高度の柔軟性, 振動 吸収性、シール性などの特長を有する。

これらに導電性機能が加わった導電性ゴムは, 近年の エレクトロニクス技術の発展により各種の接点材料とし ての用途を大きく広げ，独自の材料としての地位を確立 した。特に近年の電子回路の高密度実装化の傾向は接続 技術の多様化を促し種々の実装分野に導電性ゴムコネク ターが用いられている。

本稿では, 導電性ゴムの接続分野を中心とした用途に ついて解説する。

\section{2. 導電性ゴムの種類と用途 ${ }^{1 / 21}$}

導電性ゴムは使用される導電材料によりカーボン系導 電性ゴムと金属系導電性ゴムに大別される。両者ともに 実用化に当たっては, 機械的強度を損なわずにいかにし て高い導電性を有するものを得るかが大きなポイントと なる。Tab. 1 に, 導電性ゴムの導電性に影響を与える因 子とその効果を示した。

これらの基本的な効果を踏まえ, 形や質について種々 の改良が試みられ，多くの導電性ゴム製品が生み出され

*Masaki Nagata/日本合成ゴム 東京研究所

第15回講演予稿集より転載

Vol.2, No.4
ている。Fig.1に, 最近の特許出願状況からみた導電性ゴ ムの開発パターンを示す。

導電性ゴムに使用されるゴムは, ケーブル用等一部を 除きシリコーンゴムが使用される。

Tab. 1 Factors Influencing Conductivity of Conductive Rubber and Their Effect

\begin{tabular}{c|c|c}
\hline 因 子 & アクション & 効 果 \\
\hline 含有量 & 多 & 低抵抗 \\
\hline \multirow{2}{*}{ 形 状 } & 高アスペクト比 & 低抵抗 \\
& 高次構造の発達 & 低抵抗 \\
\hline 大きさ & 粗 い & 高抵抗 \\
\hline 分 散 度 & 均一化 & 高抵抗 \\
\hline 表面活性 & 高活性 & 高抵抗 \\
\hline \multicolumn{3}{|c}{}
\end{tabular}

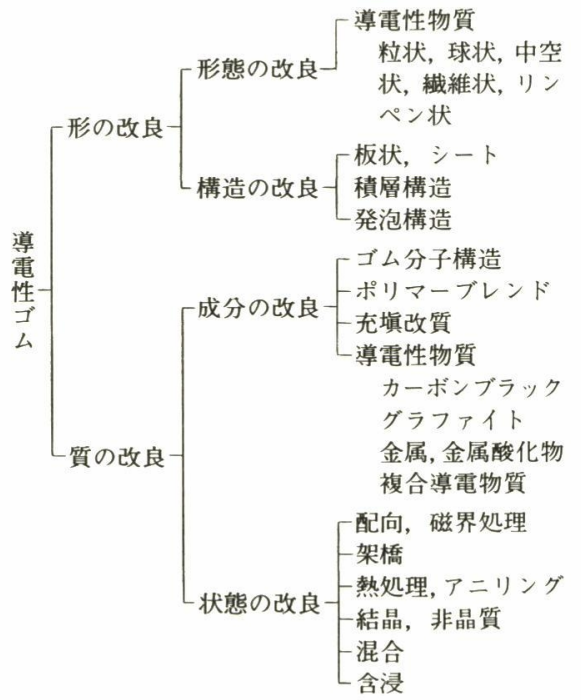

Fig.1 Development Pattern of Conductive Rubber 


\begin{tabular}{ccc}
\hline 分 類 & 構 造 & メーカー \\
\hline
\end{tabular}

1）積 層 型

東 ᄂ

$\frac{\text { 2) 導線貫通型 }}{3 \text { 3) 粒子分散型 }}$

4) 回路形成型

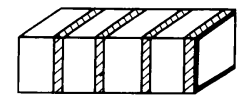

テクニット

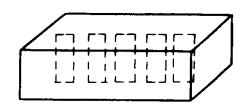

信越ポリマ

Fig.2 Types of Conductive Rubber Conectors

シリコーンゴムが多用される理由として, 耐熱性, 電 気特性が優れているほか環境特性に優れていること, ジ エン系ゴムなどで用いられる老化防止剤（導電性に悪影 響を及ぼすといわれる）を使用する必要のないこと，さ らに可塑性が大きいため導電材料の配合が比較的容易な こと等があげられる。

導電性ゴムの中で, 接続素子やスイッチ素子として使 用されるものは異方導電性ゴムや加圧導電性ゴムである。

異方導電性ゴムは, 導電特性に異方性を有する材料で, 導電部と絶縁部が積層構造をとるもの, 金属繊維や炭素 纎維を埋め込んだもの，金属粒子を配列させたものなど が商品化されている。Fig. 2 に異方導電性ゴムの代表的 なものを示す。

加圧導電性ゴムは単なる導電ゴムとは異なり, 加圧部 のみが導電性を示し, 他の部分は絶緑性を保つ材料であ る。シリコーンゴム中に金属粒子やグラファイトを混入 したものが商品化されている。

Tab. 2 に異方導電性ゴム, 加圧導電性ゴムの代表的用 途を示す。異方導電性ゴムの用途は液晶表示装置 ( LCD) とプリント回路基板 (PCB) との接続, $\mathrm{PCB}$ 間の接続等 の接続用途が中心である。一方, 加圧導電性ゴムの用途 としては, 高密度実装スイッチやPCB検査治具等のスイ ッチ用途が中心である。
Tab.2 Uses of Anisotropic Conductive Rubber and Pressure Conductive Rubber

\begin{tabular}{|c|c|c|}
\hline 区 分 & 適 用 例 & 段 階 \\
\hline 部品と PCB接続 & $\begin{array}{l}\mathrm{LCD} \text { と } \mathrm{PCB} \\
\mathrm{LSI} \text { フラットパックと } \mathrm{PCB}\end{array}$ & $\begin{array}{l}\text { 実 用 } \\
\text { 実 用 }\end{array}$ \\
\hline $\mathrm{PCB}$ 間の接続 & $\begin{array}{l}\text { ハードとフレキ } \\
\text { ハードとハード }\end{array}$ & $\begin{array}{l}\text { 実 用 } \\
\text { 実 用 }\end{array}$ \\
\hline 部 品 検 査 & $\begin{array}{l}\text { LCDの検査 } \\
\mathrm{PCB} の \text { 部分検査 } \\
\mathrm{PCB} の \text { 全面検查 } \\
\text { LSI } の \text { 検査 }\end{array}$ & $\begin{array}{c}\text { 実 用 } \\
\text { 実 用 } \\
\text { 開発 実用 } \\
\text { 開発～実用 }\end{array}$ \\
\hline スイッ千 & $\begin{array}{l}\text { 一般スイッチ } \\
\text { 透明スイッチ }\end{array}$ & $\begin{array}{ll}\text { 実 } & \text { 用 } \\
\text { 開 } & \text { 発 }\end{array}$ \\
\hline 導電シール材料 & 部分メッキ用電極 & 実用～開発 \\
\hline
\end{tabular}

\section{3．異方導電性ゴム, 加圧導電性ゴムの特性}

接続用途に使用される異方導電性ゴムは各種のものが 市販されており，種類によりその特性，特長は異なる。 ただ，この種の材料の一般的特長として，下記のことが あげられる。

（1）ギャップのある電気接続が可能

(2) 装脱着が可能

（3）接続面がシール機能を有する

（4）衝撃吸収機能を有する

（5）半田づけ等による熱的損傷を受けない

等である。特に，(1)はデジタル時計や液晶テレビのよ うな機器の構造上ギャップのある接続が必要な場合に有 効性を発揮し，(2)は接続部品の交換が必要な場合(ICの 交換など）に有効である。以下, 各種異方導電性ゴムの基 本特性, 特長を解説する。

\section{1 積層型コネクター6)}

シリコーンゴムにカーボンブラックを立壃した導電性 シリコーンゴムと，シリコーンゴムを交互に積み重ねて 共加硫等で固着した後, 所要寸法に裁断して得られる材 料であり，その外観からゼブラ型と呼ばれている。

このタイプは, Fig. 2 に示すようにチップの上下およ び前後で導電性を示し, 長手方向では絶縁性を有する。

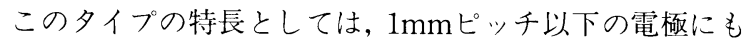
容易に対応でき, 寸法吸収能があるため電極との安定し た接触が得られること, 形状, 寸法の自由度が大きく長 サイズや厚い物も作りやすいこと等があげられる。

一方, 短所としては, カーボン系導電ゴムを用いてい るので導通抵抗值が高く $\left(10^{0} \sim 10^{3} \Omega\right)$, また電流容量も 小さい $\left(5 \mathrm{~mA} / \mathrm{mm}^{2}\right)$ ため用途的にLCD用コネクターに限 
定されること， 2 方向に導電性を有するため 2 次元に配 置された電極の接続には不向きであること等があげられ る。

このタイプは，実用化の歴史も比較的古く，形状や導 電部間ピッチにも種々のバリエーションがある。たとえ ば，Fig. 3 に示すように，サイド部をゴム，スポンジな どで補強し，コネクターの座屈を防ぐとともに接触面積 が大きくとれるようにしたものなどが知られている。導

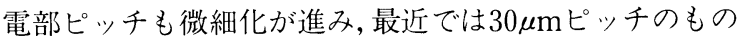
も市販されている。

\section{2 導線貫通型 7$)$}

金属繊維または炭素繊維をシリコーンゴムシートの厚 み方向に配向，貫通させたものである。

厚み方向にのみ導電性を有し，面方向に絶縁性を有す る。繊維はシート表面より 10～20 $\mu \mathrm{m}$ 程度突出している場 合が多い。代表的なものをFig. 4 に示す。

このタイプの特長として特に，金属繊維を使用したも のでは, 導通抵抗が低く（数十 $\mathrm{m} \Omega$ 数百 $\mathrm{m} \Omega$ ) 電流容量 が大きい $\left(500 \mathrm{~mA} / \mathrm{mm}^{2} \sim 5 \mathrm{~A} / \mathrm{mm}^{2}\right) こ と, 7 \sim 8$ 本 $/ \mathrm{mm}$ の高い分解能が得られること，2 次元に配置された電極 の接続に適していること等があげられる。

短所としては, 過荷重により繊維の座屈を生じやすく, その場合回復が不可能なこと。繰返し圧縮の耐久性が比 較的悪いこと等があげられる。

最近は，これらの短所を改良する試みもなされており， たとえばFig. 5 に示すような，金属繊維をたわめた形状 にしてゴム中に埋設したものが知られている。

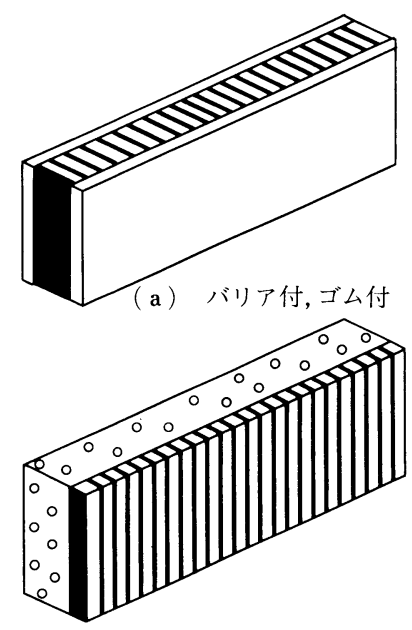

(b) スポンジ付

Fig.3 Example of Multi-Layer Type Connector

\section{3 金属粒子分散型 88}

金属粒子をシリコーンゴム中に分散させた後，金属粒 子を配向させ導電路を形成した材料である。

このタイプの特長としては, $500 \mathrm{~m} \Omega / \mathrm{mm}^{2}$ 以下の低抵 抗が得られ, 電流容量も $500 \mathrm{~mA} / \mathrm{mm}^{2}$ 程度と比較的大き いこと, 5 本 $/ \mathrm{mm}$ 程度の高い分解能が得られること, 広 い許容歪み範囲( $5 \sim 40 \%)$ を有し繰返し圧縮に強いこと 等があげられる。

短所としては, 分解能の厚み依存性があり, 実装上の 制約となることがあげられる。Tab. 3 に，この種のコネ クタ一の特性を示す。Fig. 6 に代表例を示す。

\section{4 回路形成型}

Fig. 2 に示すよjに各種のものがあるが，代表的なも のは, シリコーンゴム芯材に平行な電極パターンを有す る $\mathrm{FPCを}$ 卷きつたものである。

一般的特長としては，低抵抗で厚いものを得ることが できることがあげられ，短所としてはリジットな回路面 が外面となり, 電極との安定した接触, シール性を保つ のが困難なことがあげられる。

\section{5 金属粒子偏在型, 導電ゴム偏在型 99,10$)$}

Tab.1で示したタイプのほか, 注目すべきものとして, 金属粒子偏在型，導電ゴム偏在型がある。

金属粒子偏在型は，配合した金属粒子をシリコーンゴ

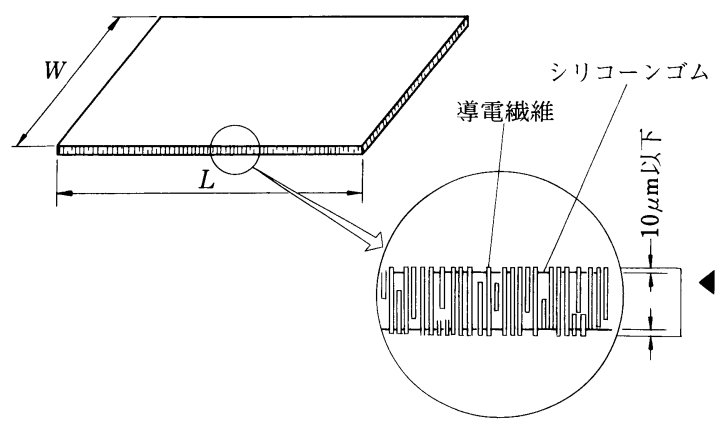

Fig.4 Fiber Implant Type Connector

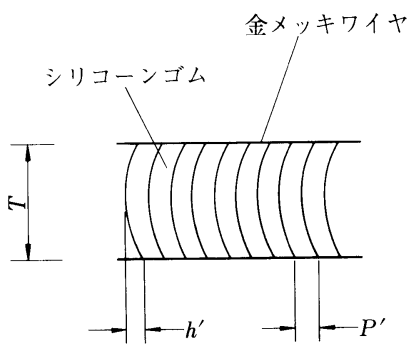

Fig.5 Type Using Bended Metal Fiber 
Tab.3 Specific Characters of Metal Dispersion Type Connector

\begin{tabular}{c|c|c|c|c}
\hline JSR PCR & $305-02$ & $305-05$ & $304-10$ & $301-05$ \\
\hline 最小電極面積 $\left[\mathrm{mm}^{2}\right]$ & 0.2 & 0.6 & 1.0 & 0.6 \\
\hline 最小電極間隔 $[\mathrm{mm}]$ & 0.1 & 0.1 & 0.5 & 0.3 \\
\hline 分解能 $[$ 本 $/ \mathrm{mm}]$ & 5 & 3 & 1 & 1.5 \\
\hline 厚 き $[\mathrm{mm}]$ & 0.20 & 0.42 & 0.90 & 0.43 \\
\hline
\end{tabular}

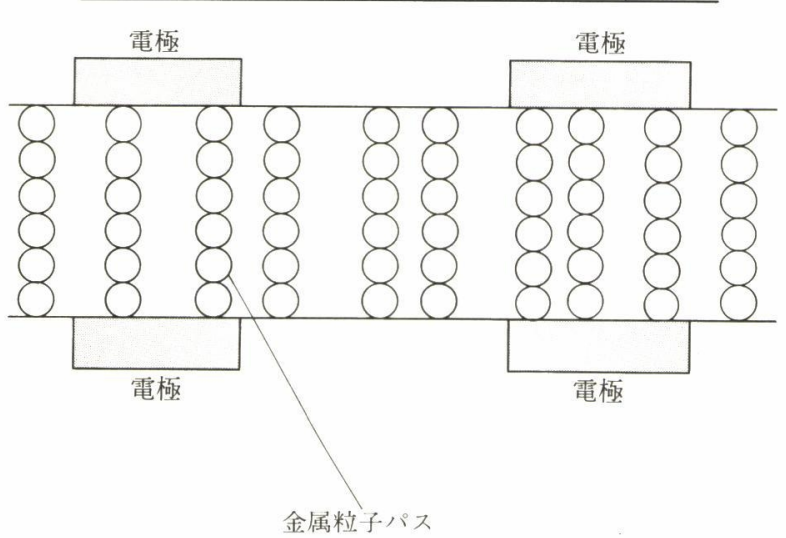

Fig.6 Principle of Metal Dispersion Type

ムシート中に所定のパターンで偏在させたもの) Fig. 7参 照）である。導電ゴム偏在型は，導電ゴムのチップを絶 縁シート（ゴム，プラスチック）の中に所定のパ夕ーン で組み込んだものである。

特長としては, 微細な導電部( $0.1 \mathrm{~mm}^{2}$ 以下) の形成が 図れることから, 微細な 2 次元配置電極の接続に適して いる。

\section{6 異方導電性膜 (接着タイプ $)^{111}$}

以上の異方導電性ゴムは, マトリックスとしてシリコ ーンゴムが用いられており，圧接接続に用いられるタイ プである。

これに対し, 最近, マトリックス成分を変えてヒート シール性（熱接着性）をもたせたものが市場に現われて きた。

シリコーンゴム系に比べ, 分解能, 環境信頼性に難が あるといわれているが, 実装上のメリットが得られる場 合も多く，新なな用途への展開が注目される。(Fig.8)

\section{7 加圧導電性ゴム ${ }^{12}$}

加圧導電性ゴムは, 加圧部のみが導電化することから, 一種の異方導電性ゴムと見なすこともできる。ただ，そ のスイッ千機能 (Fig.9,10) から, 用途的には上記の異 方導電性ゴムとは異なり，スイッチ素子としての用途が 26

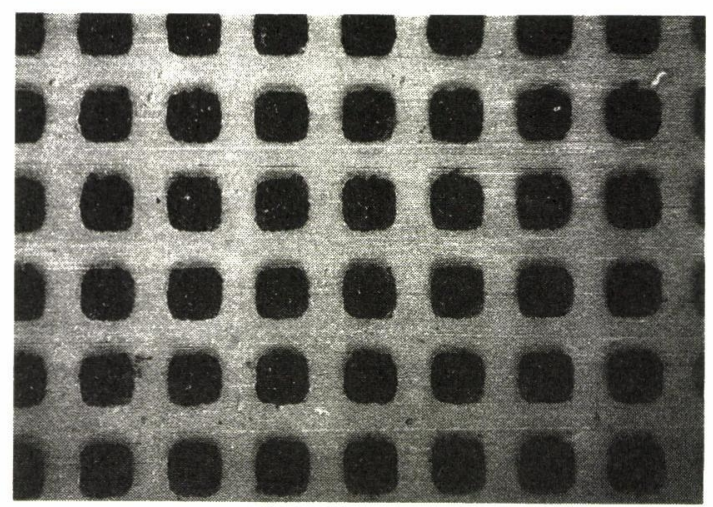

Fig.7 Metal Grain Designed Distribution Type Connector

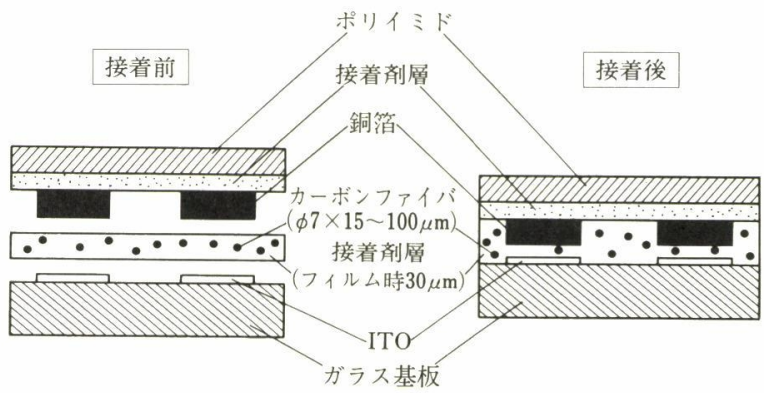

Fig.8 Assembly of an Anisotropic Counductive Film

ほとんどである。

\section{4. 導電性ゴムの実装技術}

\section{1 異方導電性ゴムの各種実装技術}

異方導電性ゴムを接続用途に使用するに当たっては, 一般的に次の点が配慮されなければならない。

(1) 電極ピッチ, 電極ギャップへの適合性

(2) 電気特性（導通抵抗, 電流容量, 絶縁抵抗)

（3）機械特性（圧縮弾性率，許容企及量）

（4）装着時の環境信頼性（高温高湿, サーマルサイク 几，耐薬品性等）

（5）加工メリット（装着の容易性，コスト等）

これらのことを配慮して, 最適な異方導電性ゴムが選 択される。

異方導電性ゴムの応用として最も代表的なものは, Fi g.11 に示すようなデジタルウォッチや電卓の LCD と PCB の接続である。ギャップが広く，低い抵抗值である必要 もないことから、この用途には積層型コネクターが用い られる。

フレームを用いて圧接固定され, 5 〜 $15 \%$ の圧縮歪み量 で使用される。

最近, 応用が注目されているものでは LCD, EL 等の

HYBRIDS 


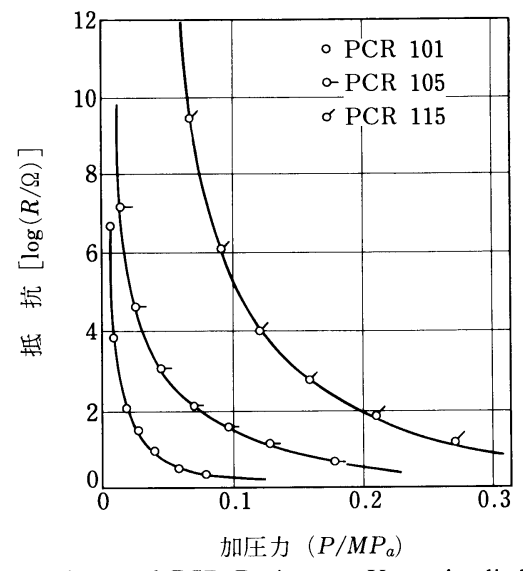

Fig.9 Dependence of PCR Resistance Upon Applied Pressure

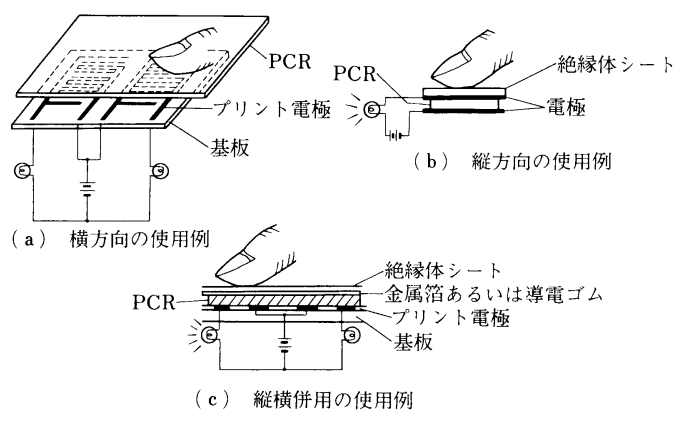

Fig.10 Application of PCR as a Switch

フラットパネルの実装技術への適用がある ${ }^{13)}$ 。Fig.12

Fig.13に, 異方導電性ゴムを使用した実装例を示す。ここ で,Fig.12(a)のIC一パネル間の接続以外はすべて回路 基板一パネルの接続であり，要求特性(たとえば，ELパ ネルではLCDパネルよりも低抵抗, 高電流容量が必要) に応じて積層型,導線貫通型, ヒートシール型等各種のコ ネクターが用いられる。

IC一パネル間の接続には，金属粒子偏在型か導電ゴム 偏在型が用いられている。使用される ICは一種のフリッ

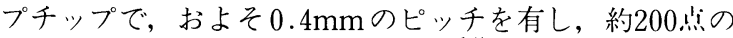
パッドをもったものである(Fig.14) $)^{14)}$

この種の IC一パネルあるいは IC-PCB の接続用途 (Fig.15)は, 最近のICのリードレス化, 電極間ピッチの微 細化，多ピン化の動向と相まって表面実装技術としての 応用が期待されている。特に，多数の微細ピッチのICを 同一基板上に実装するような場合，その歩留りを保つた めに検査工程時における IC 交換作業が容易に行なえる 必要がある。こういった意味で，今後，この種の用途で の展開が期待される。

Fig.16に, PCB 間相互の接続に金属粒子分散型を使用 した場合の例を示す。実装上の特色としては，メカニカ

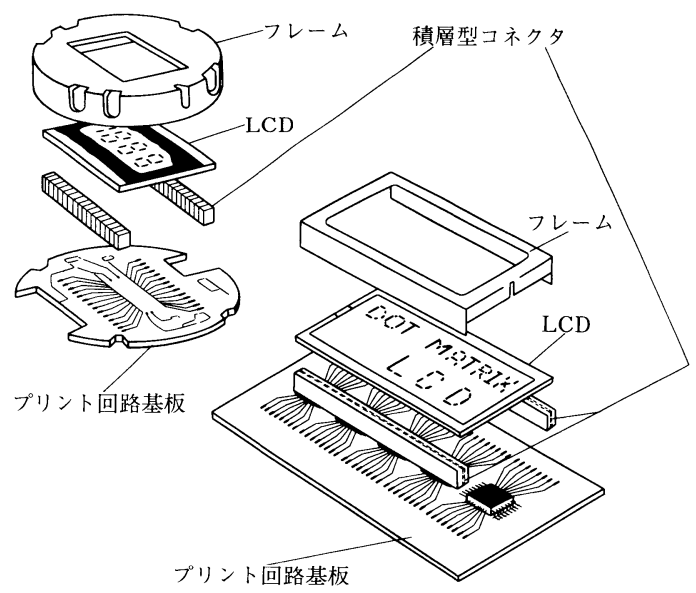

Fig.11 Appication of Multi-Layer Type

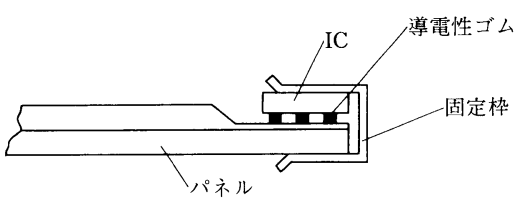

( a )

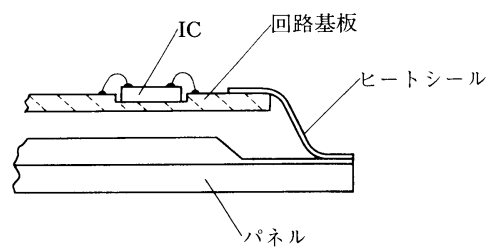

(b)

Fig.12 Assembly of a Small Size Liquid Crystal Flat Panel

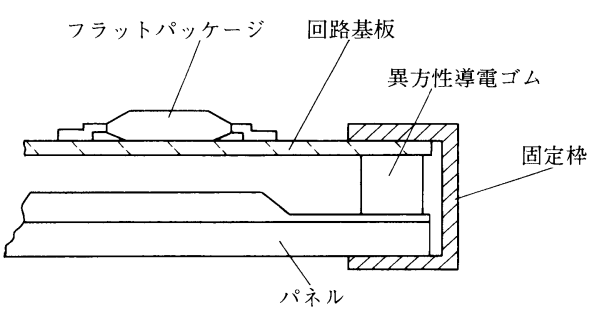

(a)

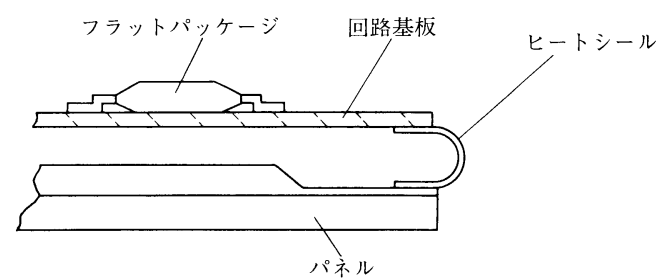

(b)

Fig.13 Assembly of a Large Size Liquid Crystal Flat Panel 
ルコネクターに比べ薄型化省スペースが可能となり, 組 立工数の削減も図れることである。このような方法で,

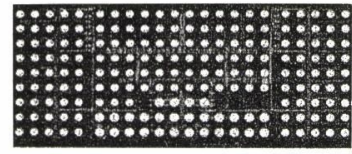

(a) AuバンプをつけたLSIチップ

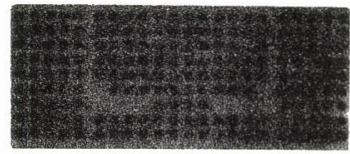

(b) 導電性ゴムコネクタ

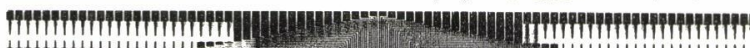

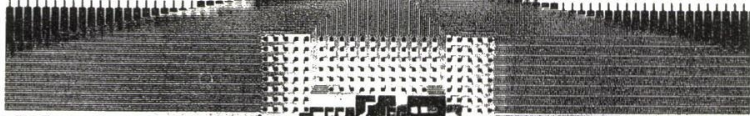

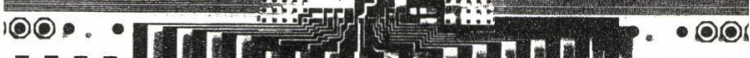

inificimum

(c) 液晶パネル・ガラス基板上の接続パッド

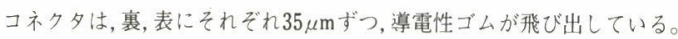

Fig.14 Connection Example of a Liquid Crystal Panel Glass Board

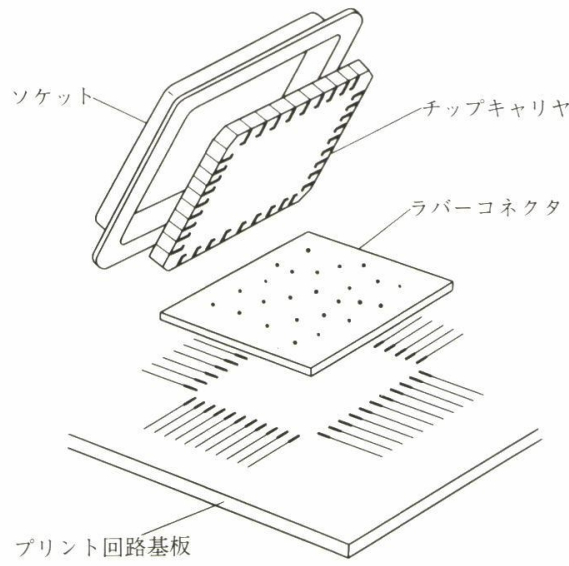

Fig.15 Connection Example of an IC-PCB

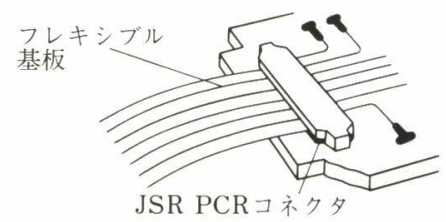

（a）帯状での使用方法

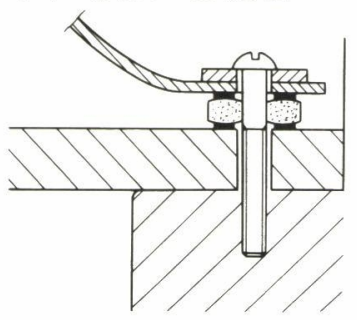

（b）リング状での使用方法

Fig.16 Application of Metal Dispersion Type Connector
ワープロなどのOA機器内部の配線接続に用いられてい る。

$\mathrm{PCB}$ 間相互の接続用途としては,このほかにもカメラ 内部のフレキ基板間の接続等に導線貫通型やヒートシー ル型が使われている。

\section{2 加圧導電性ゴムの実装技術}

加圧導電性ゴムは，その特性を生かし種々のスイッ千 素子への応用が可能である。これまでに, 日本語ワード プロセッサーなどに用いられている多項目入力タブレッ トや図形入力装置等への応用がなされてきている。

最近は他の素材との複合化による紐状のコードスイッ 千への応用 ${ }^{15)}($ Fig. 17) や, 基板検査治具等のシステム機 器への応用 ${ }^{16)}($ Fig.18)が注目されている。

コードスイッチは，加圧導電性ゴムを極細束銅線の柔 軟性のある電極ではさむ簡単な構造であり, 耐水性, 而 候性，耐熱性，耐薬品性に優れた屈曲自在の夕ッチスイ ッチである。産業安全や防犯，防災用地滑り唡出などの センサー用途での応用が汹られている。

加圧導電性ゴムはまた，多数の場所を同時に押しても 互いに電気的には絶縁が保たれ，かつ個々の押圧点で弾 性に富むため, 2 次元的に配置されている多数の電極と の同時接続が可能となる。この特性に着目して, 応用が なされたのが PCB 検査装置治具である。この用途では, 密閉構造ではない（スイッチ機能は要求されない）なめ 他の異方導電性ゴムの適用も原理的に可能であるが，低 抵抗，耐久性が要求されることから金属粒子を用いた采 が最も適していると考えられる。

\section{5.まとめ}

異方導電性ゴム, 加圧導電性ゴムの種類, 特性, 用途 等につき解説してきたが, 今後ともさらに需要の多様化, 高度化に即し, 多品種化, 機能性の向上が図られててい くものと思われる。

特に, 現在急激に進展している機器の高密度実装化に

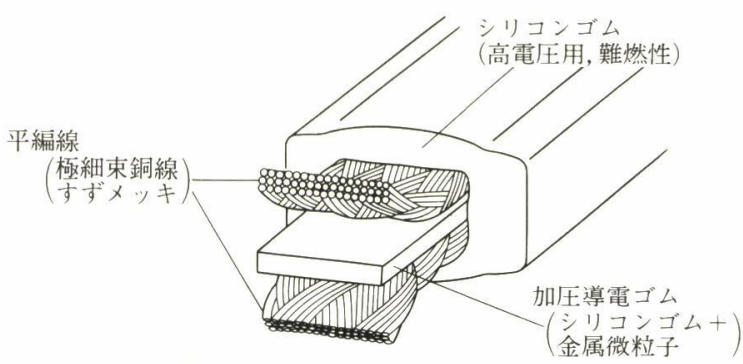

Fig.17 Structure of Code Switch 


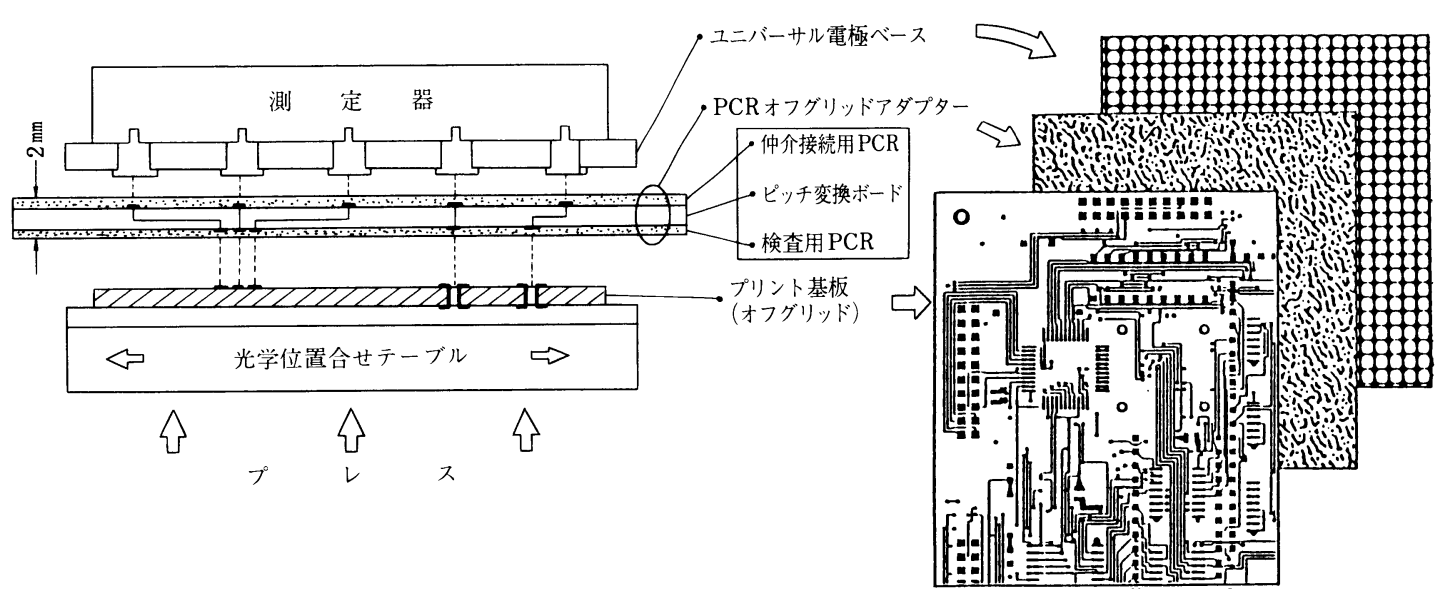

Pig.18 Printed Circuit Board Tester Using PCR

対応し得る実装技術の確立を図っていくことが重要であ り，材料メーカ一側と組立メ一カ一側とのより密な協力 関係が必要である。

\section{参 考 文 献}

1）柿沢紀世雄：日本ゴム協会誌，58(9)，553,(1985)

2）永田正樹：日本ゴム協会誌，58(9)，604，(1985）

3）米合平入郎：日本ゴム協会誌，58(9)，610，（1985）

4）安田直史, 永田正樹：材料フォーラム, No.2, 79, (1985)

5）安田直史, 永田正樹：材料フォ一ラム, No.3，117, (1986)

6）根井鴻一：電子材料, 23(12)，49, (1984)

7）椎野光男：電子材料，23(7)，69, (1984)
8）永田正樹, 藤村峰夫：信学技報, CPM 85-24, (1985)

9) 安田直史, 永田正樹：マイクロエレクトロニクスシンポジウム 論文集, p.90，（1985）

10）飯沼芳夫, 小嶋敏夫, 岡野明彦：マイクロエレクトロニクスシ ンポジウム論文集, p.106, (1985)

11）有光義雄, 桜田五十二：電子材料, $22(10), 50$, (1983)

12）永田正樹, 安田直史：日本金属学会会報, 17, 991, (1978)

13）畑田賢造，松永浩二, 藤本博昭：電子材料, 24(9), 49, (1985)

14）マイクロデバイセズNo.2 (日経エレクトロニクス別冊), p.44, (1984)

15）富田誠介：高分子, 35(5)，475，(1986）

16）中江浩一, 藤村峰夫：電子材料, $23(10), 158$, , (1984) (p.33よりつづく)

題のないレベルの信頼性を有していることが確認できた。

\section{5. 今後の展望}

今後 LCD実装としては, 接続ピッチの細密化および接 続端子数の増大がますます進み, かつコストダウンの要 求も非常に強くなってくるのは必至である。したがって, これらに対応して, 次のような方向へ進んで行くと考え る。

（1）ピッチの細密化に対応するために, ヒートシール 等に代わって異方性導電膜の適用が拡大する。
（2）ドライバIC 数の増大に対応して，高密度実装性 から COPの比率が増す。

（3）コストダウンのため, ドライバICのバンプレス 化が図られる(Bumped-TAB 化等)。

\section{参 考 文 献}

1）畑田他：フィルムキャリヤ方式によるフラットパネルの実装, 電子材料, $(1985.9)$

2）畑田他：光硬化性樹脂によるフラットパネル電極接続の基本特 性とモジュール構成, 信学技報, vol.85, No.35, (1986.3)

3）舛田：液晶ポケットテレビの高密度実装, インターネプコン講 演, (1986.1) 